\title{
Interaction of manganese with striatal dopamine turnover in human alpha-synuclein transgenic mice
}

\author{
Tamara M Peneder ${ }^{1}$, Michael Berger ${ }^{1}$, Petra Scholze ${ }^{1}$, Georg Heinze ${ }^{2}$, Johanna Bertl', Jan Bauer', \\ Oleh Hornykiewicz', Eric K Richfield ${ }^{3}$, Christian Pifl ${ }^{1 *}$ \\ From 16th Scientific Symposium of the Austrian Pharmacological Society (APHAR) \\ Vienna, Austria. 25-27 November 2010
}

\section{Background}

It is thought that the interaction of genetic and environmental factors is an important risk factor for Parkinson's disease (PD). $\alpha$-Synuclein $(\alpha$-syn) is a protein of special interest in PD because mutations in $\alpha$-syn (A53T or A30P or E46K) lead to PD. Manganese ( $\mathrm{Mn}$ ) is a heavy metal known to cause parkinsonian symptoms. Therefore, we investigate the effect of manganese $(\mathrm{Mn})$ on human $\alpha$-syn-expressing mice.

\section{Materials and methods}

C57/Bl6 mice expressing either human $\alpha$-syn or the A53T/A30P doubly mutated human $\alpha$-syn under the tyrosine hydroxylase promoter and nontransgenic sister mice were exposed at the age of 4 month to either $\mathrm{MnCl}_{2}$ (1\%) enriched or control food. Locomotor activity was quantified every 2 months using automated activity chambers. Mice were sacrificed at the age of 7 or 20 months. Tyrosine hydroxylase positive cells in the substantia nigra pars compacta were quantified in a blinded manner. Neurochemical analysis of neurotransmitters and amino acids was performed in the striatum using high performance liquid chromatography.

\section{Results}

Mobility was increased by Mn, no significant difference due to the transgenes could be found. Striatal Mn content was significantly increased about threefold. Quanti-

* Correspondence: christian.pifl@meduniwien.ac.at

${ }^{1}$ Center for Brain Research, Medical University of Vienna, 1090 Vienna, Austria Full list of author information is available at the end of the article fication of dopaminergic cells in the substantia nigra pars compacta showed a significant cell loss in aged mice $(-10 \%)$ but no effect of $\mathrm{Mn}$ or transgenes (3-way ANOVA with factors gene, $\mathrm{Mn}$ and age). In 7 months old mice, neurochemical analysis showed interactions between transgene and $\mathrm{Mn}$ exposure for the ratio homovanillic acid : dopamine as well as aspartate (2-way ANOVA with factors gene and $\mathrm{Mn}$ ). These values were increased in human $\alpha$-syn-expressing compared to nontransgenic mice which were control-fed (17 and 11\%, respectively). There was no increase when animals obtained Mn-enriched food. Contrary, mutated $\alpha$-synexpressing mice showed an increase compared to nontransgenic and human $\alpha$-syn-expressing mice only when they obtained Mn-enriched food. Analysis of the same parameters in the 20 months old mice did not reveal any significant changes.

\section{Conclusions}

Under our experimental conditions, $\mathrm{Mn}$ and $\alpha$-syn, wild-type and doubly mutated, did not induce signs of neurodegeneration, neither separately nor in interaction. However, Mn interferes with the dopamine system through human $\alpha$-syn: manganese exposure decreased DA turnover in the striatum of mice expressing human $\alpha$-syn wild-type. This effect was lost by the two parkinsonism inducing mutations.

\section{Acknowledgements}

Supported by the Medical-Scientific fund of the Mayor of Vienna \#2578 to C.P.

\section{Author details}

${ }^{1}$ Center for Brain Research, Medical University of Vienna, 1090 Vienna, Austria. ${ }^{2}$ Core Unit for Medical Statistics and Informatics, Medical University 
Published: 16 November 2010

doi:10.1186/1471-2210-10-S1-A16

Cite this article as: Peneder et al: Interaction of manganese with striatal dopamine turnover in human alpha-synuclein transgenic mice. BMC Pharmacology 2010 10(Suppl 1):A16.

Submit your next manuscript to BioMed Central and take full advantage of:

- Convenient online submission

- Thorough peer review

- No space constraints or color figure charges

- Immediate publication on acceptance

- Inclusion in PubMed, CAS, Scopus and Google Scholar

- Research which is freely available for redistribution

Submit your manuscript at www.biomedcentral.com/submit
C Biomed Central 